\title{
Archaeological Research on Migration as a Multidisciplinary Challenge
}

\section{Stefan Burmeister*}

Migration is a key concept in archaeology. It is a common explanation for the distribution and diffusion of cultural traits. However, it is more often an axiomatic postulate than the result of sound methodological analysis. The weaknesses of this approach have become apparent and have brought migration-as-explanation into disrepute. For archaeological investigation of the Migration Period the problem is further aggravated. Ancient written sources report an abundance of migrations associated with particular peoples. These sources often provide the coordinate system of archaeological investigations with fatal consequences as archaeology runs the risk of losing its independent methodological basis. Recently, new methods derived from the life sciences have joined in and have created new approaches to migration analysis. These methods sometimes provide a corrective that can compensate for the weaknesses of archaeology's own methodology. Archaeology now faces new challenges. Archaeological sources are often neither compatible with written sources, nor with the findings of the diverse life science methods. It is becoming apparent that archaeology has lost its previous methodological command for investigating migration. As a scientific discipline archaeology has to finds its place in migration research anew.

Keywords: archaeology; migration; genetics; Anglo-Saxons; Indo-Europeans.

Migration is a key concept in continental European archaeology. According to the discipline's tradition, migration was - and still is - reckoned as a major cause of cultural change. In retrospect, however, it must be said that migration itself was largely absent as a subject of research in its own right. Mobility is in continental European archaeology a common explanation for the spatial distribution of archaeological finds - but this only as an axiomatic assumption of observed phenomena. ${ }^{1}$ Neither is migration in itself seen in need of explanation - and thus seen as a genuine research topic - nor has the explanatory potential of the phenomena of culture change been reflected. Above all, we have to assert an obvious methodological lack of clarity in differentiating between migration and other potential causes of culture change. A clear theoretical distinction between different cultural mechanisms which lead to culture change has for long been neither systematically drawn nor reflected. The unclear distinction between independent development, diffusion - e. g. by trade and other forms of knowledge and culture transfer - and migration is a significant shortcoming of archaeological analysis. All three phenomena causally affect the spatial distribution of certain cultural features, but only migration is necessarily linked to the mobility of groups.

\footnotetext{
* Correspondence details: Stefan Burmeister, VARUSSCHLACHT im Osnabrücker Land gGmbH, Museum und Park Kalkriese, Venner Straße 69, 49565 Bramsche-Kalkriese, Germany. Email: burmeister@kalkriese-varusschlacht.de. Cf. Burmeister, Migration und Ethnizität.
} 
Bruce Trigger already complained about this methodological deficit in archaeology in the $1960 s ;{ }^{2}$ systematic approaches to solving the problem have not been developed since: a missing theoretical comprehension of prehistoric migrations and their study is still criticized today. ${ }^{3}$ In the Anglo-American world, with the $>$ New Archaeology<, migration as an explanatory model for culture change was abandoned and banished from the gaze of archaeological research. However, archaeology's rejection of migration is not primarily rooted in the methodological shortcomings of migration-as-proof, but more so in the rejection of the discipline's cultural and historical tradition, as well as in a shift to an evolutionistic paradigm. ${ }^{4}$ Lewis Binford, one of the protagonists of the 'New Archaeology<, saw migration as an exclusively historical explication that affects a mechanism of cultural processes, but "ad$\mathrm{d}[\mathrm{s}]$ nothing to the explanation of the processes of culture change and evolution $"{ }^{5}$ Because migrations are specific events and not the result of evolutionary processes, they offer no general explanation to the reference frame of the structural and functional characteristics of cultural systems - and thus would have no explanatory power in the matter of processes of culture change. ${ }^{6}$ This is remarkable insofar as Binford made White's dictum of culture as an "extra-somatic means of adaptation for the human organism" the basis of his disciplinary re-adjustment. Migration could fit easily into this cultural concept, however it lacked a basic understanding of the processual character of migration. The vast number of historical and present migrations reveals mobility as an adaptive strategy in dealing with changing ecological, economical and political conditions. Only later did the multifaceted processual character of migration find its way into the archaeological discourse. ${ }^{7}$ This lack of methodological and theoretical comprehension should not lead to letting the field of research lie fallow in general. In fact, David Anthony later remarked that here was a case of the baby being thrown out with the bathwater. ${ }^{8}$

The history of mankind is a history of migrations. Migration is considered to be a part of the human condition ${ }^{9}$ - the human being as a homo migrans..$^{10}$ The historical potency of migration especially in late antiquity has been discussed; whether the so-called barbarian migrations really caused the end of the Roman Empire will remain undecided here. In any case, migrations changed the political map of Europe as well as the social structures of societies to a large extent. In this sense, Walter Pohl spoke of "migration as the cradle of Europe ${ }^{11}$ To eliminate migration as a research topic would be culpable, as that would be to

2 Trigger, Beyond History, 26-47.

3 Cabana, Problematic Relationship, 25; van Dommelen, Moving On, 479.

4 E. g. Adams, Invasion, Diffusion, Evolution; Adams et al., Retreat from Migrationism; Myhre and Myhre, Concept >Immigration<.

5 Binford, Archaeology as Anthropology, 218.

6 The New Archaeology strongly aimed at generalisations of cultural processes, which is opposed to a study of historical events disqualified as particularism. For a critical review of New Archaeology/Processual Archaeology see Eggert, Prähistorische Archäologie und Ethnologie; Trigger, History of Archaeological Thought, 294-303.

7 Seminal: Anthony, Migration in Archeology; in later variations: Burmeister, Archaeology and Migration; Prien, Archäologie und Migration; Tsuda et al., Unifying Themes.

8 Anthony, Migration in Archaeology.

9 Bade et al., Enzyklopädie, 19; Fassmann, Migration.

10 Bade et al., Enzyklopädie, 19; Burmeister, Homo migrans.

11 Pohl, Entstehung des Europäischen Weges. 
make an important aspect of cultural processes invisible. Above all, migration is part of the research agenda of the archaeological disciplines. For about two decades methodological development in the natural sciences has made isotope analysis and genetics available methods that can overcome the methodological problems of archaeological research on migration and provide the first reliable proof of prehistoric migrations. Thus, archaeology seems to have a repertoire of methods at hand that should convince even notorious sceptics of archaeological migration studies. The fact that the results obtained here are now observed with great public interest may also have led to the veritable research boom that has arisen. The abundance of research projects and publications can hardly be overlooked. Although the projects are interdisciplinary and all involve close cooperation between the natural sciences and humanities, it is obvious that archaeology plays only a subordinate role in knowledge production. Despite the euphoria about these new opportunities, it makes sense to step aside for a moment and reflect upon the methodological foundations of migration archaeology and its evidence, and also to determine the relationship of the disciplines involved. In the following, the main focus will be on the German archaeological discourse, which has been very lively and controversial in recent decades. The methodological and theoretical problems of migration archaeology clearly come to light here.

\section{Material culture as methodological tool}

Migration, culture transfer and acculturation have long been studied by archaeology. The necessary methodological lever provided by material culture is tangible in the archaeological record. The spatial distribution of specific cultural features - including both things and knowledge - with subsequent expansion or relocation mirrors mobility processes; as these features did not spread by themselves, we seize here upon the mobility of the people who distributed them. Mapping is a heuristic device for further investigation, but provides no explanation in itself for the processes underlying the distribution. Although earlier voices may have warned against postulating migration solely on the basis of individual cultural features ${ }^{12}$ this often was - and still is - the usual practice. In particular, in the archaeology of migration periods the spread of individual types of costume elements is seen as evidence of a people's migration. ${ }^{13}$ This is certainly seen in the context of historical background knowledge; but in this way archaeology at best illustrates ancient textual evidence: an independent interpretation is not given. Costume elements - mostly made of metal - are not only numerous in the archaeological record - and thus represent a quantitatively significant source - they also touch on the common assumption that costumes reflect the self-concept of their wearers. It may be marked here only in passing that metallic jewellery constitutes only a very small facet of costume and perhaps reveals more about craft traditions and the distribution circuits of metalsmiths than about the representational needs of costume wearers. It is undisputed that costume is an important medium of social communication and interaction. It allows individuals to express their social affiliation and thus has great significance for forming one's identity. The problem, however, is the common understanding of costume, which has its origins in the movements of the nineteenth and early twentieth centuries that aimed at producing and preserving tradition.

12 Hachmann, Ostgermanische Funde der Spätlatènezeit; Werner, Verbreitung frühgeschichtlicher Metallarbeiten, 78 .

13 E. g. Böhme, Ende der Römerherrschaft in Britannien. 
It is based on a very static concept of costume and misunderstands what many ethnographic studies demonstrate: that is, that costumes in many cases originate in specific historical situations and transform over the course of social processes. They are by no means permanently tied to a specific group. ${ }^{14}$ This ethnographic perspective on costume is also supported by historical studies. ${ }^{15}$

The ambivalence concerning the interpretation of the archaeological record becomes evident in the case of the Visigoths' immigration into Spain. As a result of the downfall of the so-called Visigothic Kingdom of Toulouse in Gaul, there was an immigration of Visigothic groups and the foundation of a new empire at the beginning of the sixth century in Spain. Here an influx of Gothic or Gothic-inspired objects and new burial customs becomes apparent. Essentially two contradictory approaches compete for interpretation of the archaeological evidence, and both are situated within the context of the historical record. ${ }^{16}$ (1) The Spanish burial finds indicate a specific costume that can be traced back to the costume of the Černjachow-Sîntana de Mures culture in southern Ukraine and Romania. This particular culture is historically identified with the Goths. For two centuries Goths had preserved their traditional costume. This costume would permit, in combination with the textual evidence, the identification of the Spanish burials with the Visigoths. (2) In contrast to this view is Michel Kazanski's concept of a "mode danubienne «. ${ }^{17}$ What the first approach takes to be a Gothic costume, is in the latter a common Danubian fashion that originated in the amalgam of different cultural influences, especially equestrian/nomadic. The high social prestige that the Huns particularly enjoyed at the time ensured that this style was adopted by a cosmopolitan aristocracy often of Germanic descent. The sudden appearance of the Danubian fashion in Spain can indeed be seen in connection with external cultural influences, but not necessarily with migration, and certainly not with one that could be identified ethnically by costume. Barbara Sasse even goes so far as to say that after decades of migration the Visigoths had no longer a genuine material culture that could be distinguished archaeologically from that of the late Roman population. ${ }^{18}$ Both sides then bring forward their arguments, without a solution to the interpretive dilemma in sight.

This raises the fundamental question of how culture is bound to specific groups and specific situations. Units of production, distribution and consumption are seen as significant bases for the local reproduction of culture. ${ }^{19}$ Inspired by the work of Michel Foucault and Pierre Bourdieu this understanding has fundamentally changed cultural studies. Material culture is increasingly seen less as a reflection of social norms and social practices, but as a means of social communication, as a strategy for shaping social relations. It structures social actions and, as Tilmann Habermas points out, does it very effectively. ${ }^{20}$ Material culture is in a constant process of negotiation of meaning and practice. Foreign objects, especially, can experience a complete redefinition of their meaning and function in a new context. ${ }^{21}$ In par-

Cf. Burmeister, Zum sozialen Gebrauch von Tracht, 179-188, with further references.

Pohl, Telling the Difference; Rummel, Germanisch, gotisch oder barbarisch; Rummel, Habitus barbarus.

For an overview see Eger, Westgotische Gräberfelder.

Kazanski, Diffusion de la mode danubienne.

Sasse, Westgoten in Südfrankreich und Spanien, 42.

Cf. Hahn, Diffusionism, Appropriation, and Globalization.

Habermas, Geliebte Objekte, 193.

See e. g. Hahn and Weiss, Mobility, Meaning and Transformation of Things. 
ticular, immigrant societies reveal such flexibility in their cultural practices that any attempt to identify migrations archaeologically can easily be lead astray. ${ }^{22}$ In confrontation with a new ecological and social environment as well as changed economic conditions immigrants often adjust their cultural habits. The same applies to indigenous groups that respond to immigrants and new social constellations. ${ }^{23}$ All these processes cannot be depicted by a simple mapping of cultural features.

\section{Ethnic interpretation as methodological tool}

One would think that this problem does not arise in protohistoric archaeology. The abundance of ancient accounts of contemporary migrations cannot be overlooked nor ignored. The records link historical events with tribal names and geographical entries. Thus they offer a historical coordinate system to archaeological interpretation. It is therefore hardly surprising that such diverse information has a large impact on archaeological interpretations. It is hardly surprising then that under the influence of these records, migrations become an obvious model for the interpretation of foreign features on archaeological distribution maps. Interpretation seems to be easier in combination with the additional information of the ancient texts, which should be more a benefit than a burden. Furthermore, alternative interpretations are always confronted with the sdiktat of the historical evidence and may have to be reasoned more soundly than those interpretations that are close to the written sources. A link between the textual evidence and the archaeological record is made by ethnic interpretation. Archaeological distribution patterns are set in relationship with regionalised demonyms and should allow an ethnic interpretation of archaeologically identified cultural features. Cultures can be traced in their temporal displacement and can be identified by historical interpretation as migrating gentes or peoples. As easy as this procedure seems, so too does it hold as many problems. The archaeological analysis is centred on the so-called culture model. In a landmark study, Rolf Hachmann presented this concept in the 1950 s as an archaeological proof of migration. ${ }^{24}$ In his argumentation he explicitly did not refer to individual cultural elements, since these are too open to diverse interpretations. According to him, the essence of a culture will not be captured by the sum of its cultural elements, and cannot be represented by a limited number of isolated cultural traits. His thought followed a functionalist culture model that aims at the nexus between cultural features. That those specific cultural elements chosen in his study reflect this context, however, remained a postulate. Hachmann understood culture as a social organism, a unique and unrepeatable historical fact; culture in this sense would lose its integrity by transferring only individual elements. By assuming its historical uniqueness, direct connections can be established between the same culture at different locations.

22 Burmeister, Archaeology and Migration, 541-542; Migration - Innovation - Kulturwandel, 39-44.

23 In archaeology, the change of perspective was initiated by Hodder, Symbols in Action. In his ethno-archaeological studies, he not only showed how social behaviour was actively shaped by material culture, but also how this behaviour was adapted to specific group constellations, e. g. in interethnic contact. With it, he rejected to explain cultural behaviour with general, universal models as propagated by New Archaeology/Processual Archaeology, thus opening up the view again for particular historical contexts (ibid., 216 f.). However, this did not lead to putting migration back onto the agenda of Post-Processual Archaeology.

24 Hachmann, Ostgermanische Funde der Spätlatènezeit. 
In German archaeology this culture model, following Hachmann, is the fulcrum of ethnic interpretation. In a region in which a specific gens is attested historically, cultural patterns are inferred from the archaeological record; in an ideal case, these should be limited to the gens and can thus be considered intrinsic to this group of people. Elements of burial rites, costume and weapons, are identified as ethnic markers and used to identify migrations. The choice of these elements has on the one hand pragmatic reasons: since settlement finds for the respective groups are hardly known and then usually elude an ethnic approach, the focus is necessarily on funeral culture and grave goods. On the other hand, costume and burial customs are regarded as a strong expression of the self-understanding of a population. This usually remains unspoken and can only be considered as a postulate without thorough cultural reasoning. ${ }^{25}$

This approach is based on a classificatory concept of culture, ${ }^{26}$ which is made up of a static, primordial concept of ethnicity. According to this understanding ethnicity is determined by birth; this makes it possible to empirically distinguish ethnic affiliation. First of all, designated cultures are scientifically classified by archaeology with the aim of systematically structuring the archaeological record. But it is unclear here how these classifications reflect former life contexts and historical reality. The transfer of archaeological systems of order to real life contexts is in fact produced by the classifying concept of culture - but beyond its implicit assumptions, this is not sufficiently justified.

Another aspect of ethnic interpretation deals with the parallelism generated between textual and archaeological evidence and problems that are thus far unresolved. Since the historical record is the methodological starting point of archaeological ethnic interpretation, Volker Bierbrauer explicitly states that gentes names can only be used by archaeologists in the sense given to them by historians according to the current state of research. ${ }^{27}$ Recall, however, that for historians gens is not a simple concept, and one with which >Barbarian` social orders cannot adequately be represented. In no case does current historical science understand it as denoting a primordial, self-contained community of lineal descent. The term designates more accurately an open, continuously changing group of political actors, who are moreover united by a common ideology of descent. ${ }^{28}$ The use of gentile names by archaeologists therefore is hardly compatible with the historians' concept of gens.

This is an understanding of ethnicity that is currently favored in the social sciences and puts more emphasis on the process character of ethnicity. Following Stuart Hall, we must think of the construction of identity as being "produced in specific historical and institutional sites within specific discursive formations and practices, by specific enunciative strategies. ${ }^{29}$ Identity construction is therefore not a direct reflection of social conditions, but the field where social claims are negotiated. Identity discourse is thus always a means of defining

25 For further details and literature see Burmeister, Migration und Ethnizität, 237-240. For the general problem see Eggert, Prähistorische Archäologie, 273-296.

26 See Brather, Ethnische Interpretationen in der frühgeschichtlichen Archäologie, 51.

27 Bierbrauer, Zur ethnischen Interpretation, 49. - He states »daß dem Gebrauch von gentes-Namen durch den Archäologen nur jene Sinnhaftigkeit beigemessen werden kann, die der Historiker in Interpretation der Schriftquellen diesen nach dem derzeitigen Forschungsstand beimißt.«

28 E.g. Pohl, Gentilismus; Steinacher, Wiener Anmerkungen zu ethnischen Bezeichnungen; Wolfram, Germanen, 91-92.

29 Hall, Introduction, 4. 
social participation and power relations anew. One does not possess an ethnic identity, but creates one. This insight is the starting point for Walter Pohl in his methodological reflections on the analysis of strategies of identification. ${ }^{30}$ Ethnicity is not given, but is the result of historical and social processes. As he points out in numerous examples, ethnic markers lose their function as proof of origin in migration research. Although they can express discursive efforts for identity in specific cases, they say nothing about a person's origin. Historically attested demonyms are in a similar field of discourse: migrating groups merged, joined together; their gentile name could be transferred to other groups or they could adopt a new one that was more prestigious or which was assigned to them by foreign appellation. ${ }^{31}$

In the sense described here for the construction of identity, archaeological cultural models can also be thought of as strategic expressions of cultural participation. But through the processes outlined here, demonyms and material culture lose, on the one hand, their assumed bond, and on the other, their suitability as proof of migration. The determination of ethnic identity does not provide any methodological levers for an archaeological proof of migration. In a provisional appraisal, it can be attested that archaeology is lacking suitable methods to adequately study migration issues.

\section{Ideology as guideline for migration research}

The archaeological debate on migration is not only a disciplinary, but also always a social discourse. How migration is discussed often reflects a society's self-image in terms of its self-positioning in both history and in the present. Just think of the German archaeological technical term for migration period: >Völkerwanderungszeit $\iota$ - »the period of the migration of people«. This definition is well established in both technical as well as popular terminology. Although it has its firm place in the archaeological system of chronology, it has been defined historically: the Migration Period began with the arrival of the Huns on the eastern border of the Roman Empire and the crossing of the Danube by the Goths in 375 AD, and ended $568 \mathrm{AD}$ with the founding of the Lombard Kingdom in Italy. As historical cornerstones these dates are largely arbitrary. The Migration Period thus defined had no historical significance for either those people invading the Empire or for the Romans; but it did have significance for German historians who not only saw the decline of the Roman Empire but especially saw Germanic groups claiming the Roman heritage during this period. The term can be traced back to the eighteenth century, when it takes on a national perspective, and is less rooted in the historical events of the so designated /Völkerwanderungszeit than in the process of German nation-building in the eighteenth and nineteenth centuries. Friedrich Schiller, for example, envisioned these migrations as the beginning of a historical process which culminated in European nation building and the Enlightenment. He wrote in 1790: »The sword of the Vandals and Huns that reaped without mercy through the Occident, and the powerful race which occupied the cleaned scene, and from a millennial war came un-

30 Pohl, Introduction.

31 Pohl, Entstehung des Europäischen Weges, 34. - The historian Ulrich Kahrstedt stated already in 1934: »Bei allen Stammeswanderungen gilt es, sich klarzumachen, daß der Personenstand eines solchen Volkes sich ständig verschiebt, einzelne Gruppen, Familien und Personen zurückbleiben, andere sich anschließen und der Name des betr. Stammes bald einen ganz anderen Bestand von Individuen bezeichnet als vor Beginn der Wanderung" (Kahrstedt, Politische Geschichte Niedersachsens, 4). 
conquered - these are the creators of our present felicity. « $^{32}$ In contrast, in the destination areas of Germanic migration, one does not usually speak today of a "period of migration of people, " but rather of "the barbarian invasions", "les invasions barbares", "le invasioni barbariche« or »las invasiones bárbaras«, which, of course, are also modern technical terms. Whether "migration of people» or "invasion of barbarians", the ideological subtext of these different denominations can hardly be denied.

The debate on the immigration of Anglo-Saxons in England is also a very illustrative example of how those scenarios developed by historians and archaeologists are strongly influenced by ideological assumptions. From the German side, there is no doubt that, according to written records, numerous peoples from northern Germany migrated in the fifth and sixth centuries AD to Britain and formed there the nucleus of the modern English nation. For long, even in England, the idea of a mass immigration of Germanic groups and the expulsion of the indigenous British population was accepted..$^{33}$ In British archaeology a seminal article by Grahame Clark in 1966 launched a general rethinking in which the importance of immigration to England was widely denied for British prehistory. ${ }^{34}$ However, the paper finds its parallels in two other paradigm shifts at that time: one academic, in the Anglo-American turn to New Archaeology, which took a more evolutionary perspective and in which historical events such as migrations were attributed no explanatory power; ${ }^{35}$ and a contemporary historical context in which the public debate in England was marked by the Commonwealth Immigrants Act of 1962 and its racist-motivated policies against immigrants from the former colonies. ${ }^{36}$ This shift in British archaeology - referred to by critics ironically as "immobilism « - also reached Anglo-Saxon archaeology. The pendulum now swung in the opposite direction: no longer was mass immigration the favoured model, but instead the influx of small groups of warriors, who managed to establish themselves as an elite and ultimately imposed their language and culture on the British majority population. Mass immigration versus small group migration or: Where are we rooted? In the humus of Romanized Britons or with the Germanic barbarians?

It need not be emphasized that the archaeological research - here, migration archaeology - is situated in the context of its contemporary political discourse and is strongly influenced by it. ${ }^{37}$ This ideological bias is not dependent on the methodological weaknesses of migration archaeology, but it does affect the orientation of the research and thus its results. The issue

32 Schiller, Allgemeine Sammlung historischer Memoires, XXIX: "Das Schwert der Vandalen und Hunnen, das ohne Schonung durch den Occident mähte, und das kraftvolle Völkergeschlecht, das den gereinigten Schauplatz besetzte und aus einem tausendjährigen Kriege unüberwunden kam - diese sind die Schöpfer unsers jetzigen Glücks."

33 For a review of the debate in English archaeology see Härke, Entstehung der Angelsachsen, 429-434.

34 Clark attributed to British archaeology a downright invasion neurosis (Clark, Invasion Hypothesis in British Archaeology, 173). For the debate, his final sentence should have deserved more attention: »Invasions and minor intrusions have undoubtedly occurred, even if far less often than other forms of culture contact, but their existence has to be demonstrated, not assumed« (ibid., 188 - my italics).

35 Marciniak and Coles, Preface, name Clark as one of the founders of the New Archaeology, but it can be doubted that he himself would have agreed. In any case, his concept of archaeology, one that he had already developed in earlier works, clearly parallels the new disciplinary paradigm. Clark's studies had a strong focus on environmental and economic issues; he was interested primarily in adaptation strategies to natural and social environments, and in these he saw the essential motor for culture change. See Fagan, Grahame Clark.

36 Miles and Cleary, Britain, 165.

37 Härke, Archaeologists and Migrations; Härke, Wanderungsthematik, Archäologen und politisches Umfeld. 
of migration obviously touches upon questions of national self-image. The question of the continuity or discontinuity of certain groups, the historical fate of migration winners or losers - these touch upon conceptions of man and history that are the guiding themes of our scientific path to knowledge.

\section{Solutions to inherent methodological problems}

Solutions to the numerous problems and controversies shown here could be offered by scientific methods such as genetics and isotopic analysis. They provide a repertoire of methods, which focuses on the study of migration on a sounder basis. The debate on Neolithic transition has benefited considerably from these in recent years and, with respect to our understanding of these processes, constituted a significant leap..$^{38}$ Also, as to the question of Anglo-Saxon migration, scientific methods are thinning out the jumble of controversial opinions. ${ }^{39}$ The picture that emerges now is complex and varied. It shows that there were regions where complete family groups immigrated; here the indigenous population and the immigrants lived together in an apartheid society. In other regions, both groups lived in separate village communities, but had marital relationships. At the northern periphery of the Anglo-Saxon settlement probably only a small group of immigrants replaced the native elites. Although this multi-layered model is not new - similar scenarios have previously been formulated and it has also been emphasized that the Anglo-Saxon migration is not to be represented in a single, monothetic model of a uniform process ${ }^{40}-$ genetics seem now to validate this comprehensive, polythetic model.

Scientific methods provide a corrective to compensate not only the weaknesses of archaeology's own methodological basis, they are also a corrective when it comes to the intellectual proliferation of controversial, sometimes ideologically motivated representations of history. With the new scientific methods, new possibilities open up. The Mainz research project of bio-archaeometric identification of mobility in the fourth and third centuries BC shows that in Celtic Central Europe only a few people migrated in the course of their lives; most were stationary $^{41}$ - and this in a time where we have been informed by textual evidence of large migratory movements. La Tène material culture also points to far-reaching inter-regional contacts and cultural transfers. As indicated above by the Anglo-Saxon example, migration is becoming a more complex process. The models identified here put the universal model - ethnic group migrates from A to B - on the academic dump heap. The now numerous and promising results also point to a new level of understanding: migration is no longer an axiomatic explanation, but is studied as a social process in its own right. Demographic and social processes solidify and enhance our understanding of the societies under investigation.

So far everything seems to be progressing well. Looking at the pending issues too, we can be confident when we know that the natural sciences are on our side. In an interview in 2009, nine German archaeologists unanimously stated that the greatest advancements of

38 For a review of the archaeological debate see Kienlin, Von Jägern und Bauern; Bollongino and Burger, Palaeogenetische Studien zum Neolithikum; Bramanti et al., Genetic Discontinuity; Brandt et al., Human Paleogenetics of Europe.

39 Härke, Entstehung der Angelsachsen; Anglo-Saxon Immigration and Ethnogenesis.

40 E. g. Burmeister, Archaeology and Migration, 552; Hills, Origins of the English, 114.

41 Hauschild et al., Nebringen, Münsingen und Monte Bibele. 
knowledge were achieved in archaeology in recent decades by scientific methods. ${ }^{42}$ With regard to the funding of research projects, it seems likewise obvious: currently, archaeological migration research is hardly eligible without cooperation from the relevant sciences. ${ }^{43}$

\section{New problems for archaeology}

But I am still reluctant to draw a positive balance. I see archaeology being encountered by new, major challenges and academic problems. Recently, the results of a large-scale study on the colonization of the North American Arctic were presented. ${ }^{44}$ Based on genetic studies of the palaeo-Eskimos and modern Inuit the authors were able to show that the ancient processes are not fully apparent in the archaeological record. The material culture of the palaeo-Eskimos seems to mirror migration processes that are not evidenced by genetic data. According to the study, the archaeologically comprehensible processes of cultural diffusion and acculturation were based on the transfer of ideas, not on the spreading and mixing of populations.

Migration Period case studies have produced similar results. A preliminary report of the analysis of samples from the Thuringian cemeteries of Obermöllern and Rathewitz is as interesting as it is disillusioning. These early medieval cemeteries were examined in the context of a European project to gain more insight into the Langobard's migration. Individuals who can be identified as immigrants because of their isotopies, fit completely into the cultural habits of the regional population. However, those individuals who, by their burial objects, show external influences, do not provide any proof of mobility by isotope analysis. ${ }^{45}$

All of these diverse examples clearly demonstrate that the scientific data are not in alignment with the archaeological record. This is of course not a general statement but one that is derived from individual case studies and applies only to - and is only valid for - these cases. This observation, however, gives food for thought and leaves such strong statements as those given by Alexander Koch even more questionable. He postulated: »The ethnic ties of many Merovingian brooches ... cannot be dismissed « - and - "No Frank woman will have worn Ostrogothic, Thuringian or Lombard bow fibula, unless she was forced to by particular circumstances $:{ }^{46}$ A striking example is given by Doris Gutsmiedl showing the discrepancy between the origin of a certain brooch type and the origin of a person equipped with one according to isotope analysis. ${ }^{47}$ Though we are here faced again with the problem of ethnic interpretation, this also affects migration issues. First of all, Koch's quotes reveal a problematic understanding of scientific logic: the statements made are postulates which form the starting point of the investigation, not its results. What should be a result of scientific analysis only comes as a prerequisite of investigation - with the expected output. If Merovingian fibulae were ethnically bound, then the scientific results described show that individuals could change their ethnic identity entirely. Though this may correspond very well to current discourse in the social sciences, it is certainly not what Alexander Koch meant.

42 AiD-Redaktion, AiD-Jubiläum, 38-39.

43 This becomes even more important when one considers that many of the respondents in the interview today occupy key positions in the peer review process of the national funding programs.

44 Raghavan et al., Genetic Prehistory of the New World Arctic.

45 Knipper et al., Mobility in Thuringia or Mobile Thuringians.

46 Koch, Bügelfibeln der Merowingerzeit, 537: "Die ethnische Gebundenheit vieler merowingerzeitlicher Fibeln ... ist u. E. nicht von der Hand zu weisen« - and - „Keine Fränkin wird ostgotische, thüringische oder langobardische Bügelfibeln getragen haben, sofern sie nicht durch besondere Umstände dazu gezwungen wurde«.

47 Gutsmiedl, Justinianische Pest nördlich der Alpen. 
Anyhow, these observations are provocative as they clearly show us archaeology's epistemological limits. It becomes obvious that archaeology has lost its previous methodological hold on investigating migration. Maybe we are just in the same situation as archaeology was after the advent of radiocarbon dating. At that time the results of archaeological dating were not compatible with the new data of the radiocarbon method. This resulted in fierce defensive battles on the part of archaeology. That alone should warn us about fighting an unstoppable movement in the face of the loss of interpretive authority. Joseph Maran has clearly pointed at the errors of the conservative Milojčić group: the lack of reflection on their own methods.$^{48}$ We shouldn't make this mistake again. For archaeology, this demands a more open debate about the cultural and historical processes that basically structure the archaeological record. This is simply to say that we still need more open-minded reflection of current discourses in the cultural and social sciences.

\section{Genetics in archaeology}

It is undisputed that genetics has not only given archaeology new impetus, but also has great potential for the investigation of topics traditionally settled by archaeology. The results of such large-scale projects as the study of Lombard migration can therefore be expected with great anticipation. ${ }^{49}$ The project outline by Patrick Geary gives hope for the solution of many previously unsolved problems of migrations in Late Antiquity. Solely to open new perspectives for research is reason enough to understand the question asked by Daniela Hofmann "What have genetics ever done for us? « as merely rhetorical. ${ }^{50}$ But are expectations immediately a promise that gives rise to euphoria? Here it is worth taking a closer look, so I would like in the following to focus briefly on two case studies.

\section{Genetics of Anglo-Saxon migration}

Let us return to the Anglo-Saxon migration. The results delineated by Heinrich Härke reveal, as shown, a complex model of Anglo-Saxon immigration in post-Roman Britain, which seems to dissolve the academic controversies about the nature and extent of this migration. ${ }^{51}$ The immigration was neither a displacement nor even a genocide of the Romano-British population; their fate seems to have been social marginalization in an apartheid society. This appears to be supported by a number of genetic studies. The soft - albeit hard-fought - discourse of the human sciences could have come to an end by the hard facts of natural science. But this is not so; scepticism and criticism remain..$^{52}$ This raises the question of how

48 Maran, Mit den Methoden der Gegenwart, 341-342. - For Vladimir Milojčić the method of stylistic comparison provided more reliable information on the temporality of cultures. His criticism was fostered by problems of the radiocarbon method that occur unavoidably at any first application of a new scientific method. Milojčić's postulate of interpretive authority over the archaeological record and his massive statement "Indessen haben wir unwiderlegbare archäologische Tatsachen, die die Gleichzeitigkeit der Gumelnita- mit der Vinča-Kultur über jeden Zweifel erheben« (Milojčić, Absolute Chronologie der Jungsteinzeit, 10) nevertheless reveal a conspicuous overassessment of archaeological methods.

49 Geary, Rethinking Barbarian Invasions through Genomic History; Knipper et al., Mobility in Thuringia or Mobile Thuringians. See also Geary and Veeramah, this volume.

50 Hofmann, What Have Genetics Ever Done for Us? - She herself sees the strong impulses and new insights achieved through genetics in the debate of Neolithic transition and promotes a strong interdisciplinary cooperation.

51 Härke, Entstehung der Angelsachsen; Anglo-Saxon Immigration and Ethnogenesis.

52 See e. g. Hills, Anglo-Saxon DNA; Hills, Anglo-Saxon Migration. 
shard and resilient the results obtained by genetics really are. It is worth noting that the results were not based on genetic analysis of ancient DNA, but on exclusively modern DNA..$^{53}$ There were no statements made about individuals from Anglo-Saxon times, but only general statements about the ancestry of modern English people. DNA is an archive in which the individual genealogical history is inscribed - and where even distant, past migrations become apparent. Comparing modern British DNA with the DNA of other modern Europeans can indeed reveal past migrations, but it allows neither clear statements about the date of migration nor about the origin of the migrants.

The date of a migration is basically determined by probability calculations based on specific demographic parameters. The demographic composition of the migrants affects the outcome of migration in terms of the number of migrants in relation to the indigenous population. Further decisive factors are the duration of the migration and the socio-economic relationship between natives and immigrants; and also the length of a generation and the resulting reproduction rate have an impact on the genetic make-up. In addition to the Anglo-Saxon migration there were further waves of immigration to Britain in earlier and later centuries that might have had an influence on today's genetic map. Assuming other parameters, John Pattison comes to a different estimation regarding the genetic impact of Anglo-Saxon immigration. He rejects the results of those studies that argue for a massive immigration and sees the data in accordance with an elite immigration. ${ }^{54} \mathrm{~A}$ decision as to which of the underlying parameters best match the historical situation cannot be arrived at from the data itself. One can further speculate as to whether the statements made so far on the basis of modern DNA about an Anglo-Saxon mass immigration would have been so unambiguous without knowledge of the overwhelming textual evidence. Thus, the ball lies again in the field of the historical sciences. Only the analysis of aDNA permits de facto statements concerning historical subjects.

Another point is the geographical origin of immigrants estimated by today's genetic maps. The common ancestry of different populations can certainly be identified by the Y-chromosome haplotypes. If Weale et al. determine a strong genetic similarity between the present inhabitants of central England and Friesland, ${ }^{55}$ Friesland is however not yet to be designated as the home country of the immigrants to Britain. What is today Friesland has in its history also experienced a number of demographic changes, so that the gene map here can be the result of various migration processes. It would be naive to think that those regions at the moment not in the focus of immigration analysis have been historically at a standstill.

One last point should be noted here. Special attention of course is called by the postulate of an Anglo-Saxon apartheid society. ${ }^{56}$ Due to their calculations - based on modern DNA the authors come to the conclusion that during the first two centuries after conquest there occurred no significant marital relationships between Anglo-Saxons and native Britons. They

53 Capelli et al., Y Chromosome Census; Thomas et al., Evidence for an Apartheid-like Social Structure; Weale et al., Y Chromosome Evidence.

54 Pattison, Is it Necessary? - For a reply see Thomas et al., Integration versus Apartheid.

55 Weale et al., Y Chromosome Evidence.

56 Thomas et al., Evidence for an Apartheid-like Social Structure. 
assume that, for the maintenance of long-term segregation, specific social mechanisms are needed in apartheid societies. This explanation of the occurrence of modern DNA patterns is based on probability calculations of various demographic models, and was also previously formulated by historians $s^{57}$ and archaeologists ${ }^{58}$. The argumentative basis for the model of an apartheid society ultimately is not rooted in scientific data based on DNA analysis, but is based on general sociological considerations and legal texts of the seventh century. Apartheid is today seen as a discriminatory form of racial segregation; it can also be generally extended to ethnic groups. Segregation is accompanied by the denial of equal rights and is enforced through a series of laws. Apartheid is a legal system that cannot be reduced to closed marriage relations. For this, however, genetics cannot contribute any statement. The model of reproductive segregation along ethnic lines may be due to different social mechanisms. Even in today's western immigration societies, there are class barriers between the various population groups that socially proactively shape society and counteract mixing even after generations. Apartheid consequently cannot be determined from genetic analysis, but through studies of legal and social history only. A deficiency of the current debate is that the genetic analysis has so far mainly been carried out using modern DNA. I know of only two studies that are based on the analysis of aDNA. ${ }^{59}$ While Töpf et al. remain indifferent to the problem of Anglo-Saxon immigration, Schiffels et al. come to at least partially deviating results. According to them, 38 $\%$ of the modern population of eastern England can be traced back to Anglo-Saxon immigration. The Anglo-Saxon population, however, was genetically mixed, and there were no signs of strong segregation. It could even be observed that natives had a richer grave furnishings than did immigrants in the same burial ground. The model of an Anglo-Saxon apartheid society has to be rejected on this basis.

Genetics cannot yet provide a genuine contribution that solves the problems of the study of Anglo-Saxon migration. ${ }^{60}$ Its findings allow demographic processes to be modelled for at least a part of the immigration area. This provides important evidence, but cannot so far resolve the contentious issues satisfactorily. To date, genetic analysis touches only one segment of the multi-stage immigration model: those regions for which there is a mass immigration in discussion. The regions that experienced an elite immigration are not covered there. The model, which assumes various, differently structured immigrations, is not based on genetic analyses, but on archaeological and historical studies, and was formulated previously ${ }^{61}$ Despite all the attention that genetics has received here, the natural sciences have not yet reinvented Anglo-Saxon research.

57 Higham, Rome, Britain and the Anglo-Saxons, 193; Woolf, Apartheid and Economics in Anglo-Saxon England.

58 Härke, Population Replacement or Acculturation?

59 For their study, Töpf et al., Tracing the Phylogeny of Human Populations, analyzed the DNA of 156 individuals from Romano-British and Anglo-Saxon cemeteries. The study by Schiffels et al. 2016 is based on ten individuals from Eastern England (Schiffels et al., Iron Age and Anglo-Saxon Genomes). I am grateful to the reviewer for this reference.

60 For an overview see also Hedges, Anglo-Saxon Migration and the Molecular Evidence.

61 Härke, Briten und Angelsachsen im nachrömischen England; Härke, Sächsische Ethnizität und archäologische Deutung. 


\section{Genetics of Indo-European migration}

I now come to my final case study: outgoing migration from the North Pontic and Caspian steppe in the third millennium BC. In this region the so-called Yamnaya culture originated in the 4th millennium, and then spread westward about 3,000 BC into the steppe belt and to the Carpathian Basin. In central and northern Europe the so-called Corded Ware culture developed in the early centuries of the third millennium BC. It was one of the first archaeologically-identified cultures in the nineteenth century and since then there has been an ongoing controversy as to whether it was created by mass immigration or small group infiltration and acculturation. ${ }^{62}$ Already early, Corded Ware culture was associated with the spread of the Indo-European language. ${ }^{63}$

In recent years, two large-scale genetic studies have been presented that seem to bring clarification to this controversy. The basis of both studies is the use of ancient DNA. In one case, gene samples from 94 individuals were analysed, ${ }^{64}$ and in the other of 101 individuals; ${ }^{65}$ the sample material derived from both female and male individuals and could each be 14C-dated and assigned to an archaeological culture. Both studies conclude that Yamnaya culture was the starting point of a large and comprehensive migration that ultimately led to the displacement of large parts of the native populations in the immigration areas. While the results of the study of Allentoft et al. are barely exposed in detail, Haak et al. make an effort to quantify the changes in the genetic make-up caused by migration. They conclude that about $75 \%$ of the Central European genetic make-up was replaced by immigrant Yamnaya groups. This high percentage can be established for individuals of Corded Ware culture; younger samples - for instance from the Bell Beaker Culture - again showed a lower percentage: the authors explain this by another, though less profound displacement process that was triggered by Western and Central European groups.

The two studies provide strong evidence that cannot be ignored in view of the notorious controversy on the issue of migration. The results they achieve, particularly with aDNA - and thus based on historical subjects - will be, at least for archaeologists and historians, more reliable than extrapolations based on modern genetic maps. With aDNA the date of migration can be identified on firmer ground. However, with regard to the demographic processes the studies remain indifferent. The data is interpreted as a result of mass immigration, but for such an explication, demographic simulations are needed to determine the extent of genetic displacement. The controversy of Anglo-Saxon migration shows the impact that population models have on the evaluation of the genetic make-up. Thus, in a society with an immigrant group of $20 \%$ of the total population, the genetic make-up has been replaced after 15 generations by a ratio of more than $50 \%{ }^{66}$

The result of the $75 \%$ ratio of >Yamnaya-genotyper in the Corded Ware population is based on the analysis of four individuals from Esperstedt in Saxony-Anhalt. In the Middle Elbe-Saale region the Corded Ware culture began around $2750 \mathrm{BC},{ }^{67}$ the sampled individuals

62 Pro mass immigration see e. g. Harrison and Heyd, Transformation of Europe; Frînculeasa et al., Pit-Graves, Yamnaya and Kurgans; - pro acculturation e. g. Furholt, Entstehungsprozesse der Schnurkeramik, 493.

63 See Suhrbier, Und bewegten sie sich doch.

64 Haak et al., Massive Migration from the Steppe.

65 Allentoft et al., Population Genomics of Bronze Age Eurasia.

66 Weale et al., Y Chromosome Evidence, 2653.

67 Furholt, Entstehungsprozesse der Schnurkeramik, 484. 
date around 200-400 years later ${ }^{68}$ and, therefore, certainly do not belong to the generation of immigrants, but to a significantly later population. Again, without comprehensive analysis, the question remains as to when immigration exactly took place: with the first appearance of the Corded Ware culture or in a later period. In the latter case, the Corded Ware phenomenon would be the result of an acculturation process in the context of impending social change. In addition, it cannot be determined how representative the genetic data of Esperstedt is here for the Corded Ware culture in the Middle Elbe-Saale region. Against this background the postulate of comprehensive population displacements in the third millennium $\mathrm{BC}$ is to be regarded with caution.

Both studies link the migrations of the third millennium BC with the spread of the Indo-European language, with Haak et al., for example, prominently in the title of their publication. They take up an old argument that has again been strongly propagated in recent years. ${ }^{69}$ Since language is not reflected in DNA, the arguments are necessarily weak. The link between the emigration of the Yamnaya population and the spread of Indo-European is primarily based on two assumptions: (1) Language spreads through the migration of larger populations; (2) the spread of Indo-European must have occurred after the invention of the wagon, mid-fourth millennium BC. ${ }^{70}$ These assumptions have been formulated before by Indo-European studies, ${ }^{71}$ and are thus not originally connected to genetic studies. However, these assumptions cannot necessarily warrant the far-reaching implications of the studies presented. There are a number of examples which clearly show that language changes do not have to be caused by population changes or extensive migration. ${ }^{72}$ And the purely linguistic argument that the spread of Indo-European must have occurred between the end of the 4th and the close of the $3 \mathrm{rd}$ millennium also presents problems. The fact that a number of technical wagon terms are represented in all Indo-European languages, but the word for sspoker is not, dates the spread and splitting of the Indo-European proto-language to the period between the development of the wagon, mid-fourth millennium BC, and the development of spoked wheels, c. 2,00o BC. This would give us a chronological anchor point for migration that coincides well with the date determined by genetic analysis.

A serious problem remains disregarded in the postulated scenario of Yamnaya culture as the starting point of the Indo-European language expansion. Various terms from the semantic fields of farming and ploughing as well as settledness are also among the words that were already present in the Indo-European proto-language..$^{73}$ The nomadic, pastoral way of life of Yamnaya culture is however in clear contrast to this linguistic evidence. From a linguistic point of view we would not see this steppe culture as a nucleus of the Indo-European language family. And finally, it must also here be emphasized that genetics has provided an important proof of migration processes in the third millennium BC. These have to be considered in view of the recent controversies. Nevertheless, it cannot ultimately support several of the additional interpretations.

68 Haak et al., Massive Migration from the Steppe, Supplementary Information 3, 31.

69 E. g. Anthony, The Horse, the Wheel, and Language.

70 Haak et al., Massive Migration from the Steppe, Supplementary Information 11.

71 See e. g. Hettrich, Expansion des Indogermanischen. - I thank Heinrich Hettrich and Sabine Ziegler warmly for access to the unpublished book manuscript.

72 Balanovsky et al., Genetics of Indo-European Populations, 24; Gippert, Sprachwandel und Rekonstruktion.

73 For an overview see Hettrich, Expansion des Indogermanischen, 53-54. 


\section{What remains?}

It is obvious that genetics provides important results and impulses, and opens up entirely new perspectives for the historical sciences. Kristian Kristiansen sees archaeology here on the threshold of the third scientific revolution after its establishment as an independent scientific discipline and the development of the radiocarbon method. ${ }^{74}$ But we are only at the beginning here. Interdisciplinary cooperation between the sciences involved has yet to become attuned. Serious mistakes in the selection of samples have been made by genetics, ${ }^{75}$ and the quality of cooperation has often been criticized, with archaeology as a subordinate partner. ${ }^{76}$ That is all grist to the mill of the notorious sceptics among archaeologists. However, the strength of genetic analysis is highly visible. It offers - under certain conditions - methodologically sound evidence that people have migrated. The scientific approach also provides a test instrument as to what extent migrations are manifest in the material culture, and thus make an important contribution to basic archaeological research. The opening of archaeology to genetics is, therefore, not a question of sif<, but rather of show<. It is not desirable that one side only supplies the samples, the other only the data. The entire discussion process must be a joint one. On this process both sides have to come to an agreement. Robert Hedges stressed that scientific data are free from cultural and social assumptions; in principle, he says, they are objective. ${ }^{77}$ This is, in my opinion, not really the case. In the various case studies shown here, it became obvious that the genetic data are, for our research questions, in need of interpretation, and that interpretation is laden with a series of cultural and social assumptions. The scientific methods provide data that only make a statement about the genetic code or isotopic compositions in skeletal material. Human behavior is not their subject of analysis. Scientific results alone provide no historical knowledge, but have to be interpreted within the context of cultural studies. The disciplines involved must agree on the rationality of data and the logic of their interpretation. Future archaeological migration research will only develop further in conjunction with the natural sciences; but the explanations that have to be given lie mainly in the field of the humanities.

74 Kristiansen, Towards a New Paradigm?

75 See Bánffy et al., >Early Neolithic‘ Graves of the Carpathian Basin.

76 Lidén and Eriksson, Archaeology vs. Archaeological Science, 13-14; Egorova, DNA Evidence?

77 Hedges, Anglo-Saxon Migration and the Molecular Evidence, 80. 


\section{References}

Adams, William Y., Invasion, Diffusion, Evolution? Antiquity 42 (1968) 194-215.

Adams, William Y., van Gerven, Dennis P. and Levy, Richard S., The Retreat from Migrationism, Annual Review of Anthropology 7 (1978) 483-532.

AiD-Redaktion, AiD-Jubiläum: Neun Experten und ihre Sicht auf die Archäologie. 25 Jahre AiD - Rückschau und Ausblick, Archäologie in Deutschland 6 (2009) 38-43.

Allentoft, Morten E., Sikora, Martin, Sjögren, Karl-Göran, Rasmussen, Simon, Rasmussen, Morten, Stenderup, Jesper, Damgaard, Peter B., Schroeder, Hannes, Ahlström, Torbjörn, Vinner, Lasse, Malaspinas, Anna-Sapfo, Margaryan, Ashot, Higham, Tom, Chivall, David, Lynnerup, Niels, Harvig, Lise, Baron, Justyna, Della Casa, Philippe, Dąbrowski, Paweł, Duffy, Paul R., Ebel, Alexander V., Epimakhov, Andrey, Frei, Karin, Furmanek, Mirosław, Gralak, Tomasz, Gromov, Andrey, Gronkiewicz, Stanisław, Grupe, Gisela, Hajdu, Tamás, Jarysz, Radosław, Khartanovich, Valeri, Khokhlov, Alexandr, Kiss, Viktória, Kolář, Jan, Kriiska, Aivar, Lasak, Irena, Longhi, Cristina, McGlynn, George, Merkevicius, Algimantas, Merkyte, Inga, Metspalu, Mait, Mkrtchyan, Ruzan, Moiseyev, Vyacheslav, Paja, László, Pálfi, György, Pokutta, Dalia, Pospieszny, Łukasz, Price, T. Douglas, Saag, Lehti, Sablin, Mikhail, Shishlina, Natalia, Smrčka, Václav, Soenov, Vasilii I., Szeverényi, Vajk, Tóth, Gusztáv, Trifanova, Synaru V., Varul, Liivi, Vicze, Magdolna, Yepiskoposyan, Levon, Zhitenev, Vladislav, Orlando, Ludovic, Sicheritz-Pontén, Thomas, Brunak, Søren, Nielsen, Rasmus, Kristiansen, Kristian and Willerslev, Eske, Population Genomics of Bronze Age Eurasia, Nature 522 (2015) 167-172.

Anthony, David W., Migration in Archeology: The Baby and the Bathwater, American Anthropologist 92 (1990) 895-914.

Anthony, David W., The Horse, the Wheel, and Language. How Bronze-Age Riders from the Eurasian Steppes Shaped the Modern World (Princeton, 2007).

Bade, Klaus J., Emmer, Pieter C., Lucassen, Leo and Oltmer, Jochen, Die Enzyklopädie: Idee - Konzept - Realisierung, in: Klaus J. Bade, Pieter C. Emmer, Leo Lucassen and Jochen Oltmer (eds.), Enzyklopädie Migration in Europa. Vom 17. Jahrhundert bis zur Gegenwart (third edition), (Paderborn, 2013) 19-27.

Balanovsky, Oleg, Utevska, Olga and Balanovska, Elena, Genetics of Indo-European Populations: the Past, the Future, Journal of Language Relationship 9 (2013) 23-35.

Bánffy, Eszter, Brandt, Guido and Alt, Kurt W., 'Early Neolithic‘ Graves of the Carpathian Basin Are in Fact 6000 Years Younger-Appeal for Real Interdisciplinarity between Archaeology and Ancient DNA Research, Journal of Human Genetics 57 (2012), 467-469.

Bierbrauer, Volker, Zur ethnischen Interpretation in der frühgeschichtlichen Archäologie, in: Walter Pohl (ed.), Die Suche nach den Ursprüngen: Von der Bedeutung des frühen Mittelalters, Denkschriften der Österreichische Akademie der Wissenschaften, Philosophisch-Historische Klasse 322, Forschungen zur Geschichte des Mittelalters 8 (Wien, 2004) 45-84.

Binford, Lewis R., Archaeology as Anthropology, American Antiquity 28 (1962) 217-225.

Böhme, Horst Wolfgang, Das Ende der Römerherrschaft in Britannien und die angelsächsische Besiedlung Englands im 5. Jahrhundert, Jahrbuch des Römisch-Germanischen Zentralmuseums 33 (1986) 469-574.

Bollongino, Ruth and Burger, Joachim, Palaeogenetische Studien zum Neolithikum, in: Harald Meller and Kurt W. Alt (eds.), Anthropologie, Isotopie und DNA - biografische Annäherungen an namenlose vorgeschichtliche Skelette? Tagungen des Landesmuseums für Vorgeschichte Halle 3 (Halle a. d. Saale, 2010) 71-75. 
Bramanti, Barbara, Thomas, Mark G., Haak, Wolfgang, Unterländer, Martina, Jores, Pia, Tambets, Kristiina, Antanaitis-Jacobs, Indre, Haidle, Miriam N., Jankauskas, Rimantas, Kind, Claus-Joachim, Lueth, Frank, Terberger, Thomas, Hiller, Jennifer, Matsumura, Shuichi, Forster, Peter and Burger, Joachim, Genetic Discontinuity Between Local Hunter-Gatherers and Central Europe's First Farmers, Science 326 (2009) 137-140.

Brandt, Guido, Szécsényi-Nagy, Anna, Roth, Christina, Alt, Kurt Werner and Haak, Wolfgang, Human Paleogenetics of Europe - The Known Knowns and Known Unknowns, Journal of Human Evolution 79 (2015) 73-92.

Brather, Sebastian, Ethnische Interpretationen in der frühgeschichtlichen Archäologie: Geschichte, Grundlagen, Alternativen. Reallexikon der Germanischen Altertumskunde, Ergänzungsband 42 (Berlin, 2004).

Burmeister, Stefan, Zum sozialen Gebrauch von Tracht. Aussagemöglichkeiten hinsichtlich des Nachweises von Migration, Ethnographisch-Archäologische Zeitschrift 38 (1997) 177203.

Burmeister, Stefan, Archaeology and Migration - Approaches to an Archaeological Proof of Migration, Current Anthropology 41 (2000) 539-567.

Burmeister, Stefan, Homo migrans. Migration und die plurale Gesellschaft, eine Herausforderung für die archäologischen Museen, Museumskunde 77/2 (2012) 30-37.

Burmeister, Stefan, Migration - Innovation - Kulturwandel: aktuelle Problemfelder archäologischer Investigation, in: Elke Kaiser and Wolfram Schier (eds.), Mobilität und Wissenstransfer in diachroner und interdisziplinärer Perspektive. Topoi - Berlin Studies of the Ancient World 9 (Berlin, 2013) 35-58.

Burmeister, Stefan, Migration und Ethnizität: Zur Konzeptualisierung von Mobilität und Identität, in: Manfred K. H. Eggert and Ulrich Veit (eds.), Theorie in der Archäologie: Zur jüngeren Diskussion in Deutschland. Tübinger Archäologische Taschenbücher 10 (Münster, 2013) 229-267.

Cabana, Gabriela S., The Problematic Relationship between Migration and Culture Change, in: Gabriela S. Cabana and Jeffrey J. Clark (eds.), Rethinking Anthropological Perspectives on Migration (Gainesville, 2011) 16-28.

Capelli, Cristian, Redhead, Nicola, Abernethy, Julia K., Gratrix, Fiona, Wilson, James F., Moen, Torolf, Hervig, Tor, Richards, Martin, Stumpf, Michael P. H., Underhill, Peter A., Bradshaw, Paul, Shaha, Alom, Thomas, Mark G., Bradman, Neal and Goldstein, David B., A Y Chromosome Census of the British Isles, Current Biology 13 (2003) 979-984.

Clark, Grahame, The Invasion Hypothesis in British Archaeology, Antiquity 40 (1966) 172189.

Dommelen, Peter van, Moving On: Archaeological Perspectives on Mobility and Migration, World Archaeology 46 (2014) 477-483.

Eger, Christoph, Westgotische Gräberfelder auf der Iberischen Halbinsel als historische Quelle: Probleme der ethnischen Deutung, in: Bernd Päffgen, Ernst Pohl and Michael Schmauder (eds.), Cum grano salis: Beiträge zur europäischen Vor- und Frühgeschichte. Festschrift für Volker Bierbrauer zum 65. Geburtstag (Friedberg, 2005) 165-181.

Eggert, Manfred K. H., Prähistorische Archäologie und Ethnologie: Studien zur amerikanischen New Archaeology, Prähistorische Zeitschrift 53 (1978) 6-164.

Eggert, Manfred K. H., Prähistorische Archäologie. Konzepte und Methoden (Tübingen, 2001).

Egorova, Yulia, DNA Evidence? The Impact of Genetic Research on Historical Debates, BioSocieties 5 (2010) 348-365.

Fagan, Brian, Grahame Clark. An Intellectual Biography of an Archaeologist (Oxford, 2001). 
Fassmann, Heinz, Migration: Konstituens der Conditio humana, in: Reinhard Neck and Heinrich Schmidinger (eds.), Migration. Wissenschaft · Bildung · Politik 15 (Wien, 2013) 5-26.

Frînculeasa, Alin, Preda, Bianca and Heyd, Volker, Pit-Graves, Yamnaya and Kurgans along the Lower Danube: Disentangling IVth and IIIrd Millennium BC Burial Customs, Equipment and Chronology, Prähistorische Zeitschrift 90 (2015) 45-113.

Furholt, Martin, Entstehungsprozesse der Schnurkeramik und das Konzept eines Einheitshorizontes, Archäologisches Korrespondenzblatt 34 (2004) 479-498.

Geary, Patrick, Rethinking Barbarian Invasions through Genomic History, Hungarian Archaeology (Autumn 2014) 1-8. Retrieved on 12 April, 2016: www.hungarianarchaeology.hu/ wp-content/uploads/2014/11/eng_geary_14O.pdf.

Gippert, Jost, Sprachwandel und Rekonstruktion - Perspektiven und Grenzen der Heuristik, in: Heinrich Hettrich and Sabine Ziegler (eds.), Die Ausbreitung des Indogermanischen: Thesen aus Sprachwissenschaft und Archäologie. Akten der Tagung der Indogermanischen Gesellschaft vom 24. bis 26. September 2009 in Würzburg (Wiesbaden) forthcoming.

Gutsmiedl, Doris, Die justinianische Pest nördlich der Alpen? Zum Doppelgrab 166/167 aus dem frühmittelalterlichen Reihengräberfeld von Aschheim-Bajuwarenring, in: Bernd Päffgen, Ernst Pohl and Michael Schmauder (eds.), Cum grano salis: Beiträge zur europäischen Vor- und Frühgeschichte. Festschrift für Volker Bierbrauer zum 65. Geburtstag (Friedberg, 2005) 199-208.

Haak, Wolfgang, Lazaridis, Iosif, Patterson, Nick, Rohland, Nadin, Mallick, Swapan, Llamas, Bastien, Brandt, Guido, Nordenfelt, Susanne, Harney, Eadaoin, Stewardson, Kristin, Fu, Qiaomei, Mittnik, Alissa, Bánffy, Eszter, Economou, Christos, Francken, Michael, Friederich, Susanne, Garrido Pena, Rafael, Hallgren, Fredrik, Khartanovich, Valery, Khokhlov, Aleksandr, Kunst, Michael, Kuznetsov, Pavel, Meller, Harald, Mochalov, Oleg, Moiseyev, Vayacheslav, Nicklisch, Nicole, Pichler, Sandra L., Risch, Roberto, Rojo Guerra, Manuel A., Roth, Christina, Szécsényi-Nagy, Anna, Wahl, Joachim, Meyer, Matthias, Krause, Johannes, Brown, Dorcas, Anthony, David, Cooper, Alan, Alt, Kurt Werner and Reich, David, Massive Migration from the Steppe was a Source for Indo-European Languages in Europe, Nature 522 (2015) 207-211.

Habermas, Tilmann, Geliebte Objekte. Symbole und Instrumente der Identitätsbildung (Berlin, 1996).

Hachmann, Rolf, Ostgermanische Funde der Spätlatènezeit in Mittel- und Westdeutschland: Ein Beitrag zum Problem des Nachweises von Bevölkerungsbewegungen auf Grund des urgeschichtlichen Grundstoffs, Archaeologia Geographica 5-6 (1956/1957) 55-68.

Härke, Heinrich, Wanderungsthematik, Archäologen und politisches Umfeld, Archäologische Informationen 20 (1997) 61-71.

Härke, Heinrich, Archaeologists and Migrations. A Problem of Attitude?, Current Anthropology 39 (1998) 19-45.

Härke, Heinrich, Briten und Angelsachsen im nachrömischen England: Zum Nachweis der einheimischen Bevölkerung in den angelsächsischen Landnahmegebieten, Studien zur Sachsenforschung 11 (1998) 87-119.

Härke, Heinrich, Sächsische Ethnizität und archäologische Deutung im frühmittelalterlichen England, Studien zur Sachsenforschung 12 (1999) 109-122.

Härke, Heinrich, Population Replacement or Acculturation? An Archaeological Perspective on Population and Migration in Post-Roman Britain, in: Hildegard L. C. Tristram (ed.), The Celtic Englishes III. Anglistische Forschungen 324 (Heidelberg, 2003) 13-28. 
Härke, Heinrich, Anglo-Saxon Immigration and Ethnogenesis, Medieval Archaeology 55 (2011) 1-28.

Härke, Heinrich, Die Entstehung der Angelsachsen, in: Heinrich Beck, Dieter Geuenich and Heiko Steuer (eds.), Altertumskunde - Altertumswissenschaft - Kulturwissenschaft. Erträge und Perspektiven nach 40 Jahren Reallexikon der Germanischen Altertumskunde, Reallexikon der Germanischen Altertumskunde, Ergänzungsband 77 (Berlin, 2012) 429-458.

Hahn, Hans Peter, Diffusionism, Appropriation, and Globalization: Some Remarks on Current Debates in Anthropology, Anthropos 103 (2008) 191-202.

Hahn, Hans Peter and Weiss, Hadas, Mobility, Meaning and Transformation of Things. Shifting Contexts of Material Culture through Time and Space (Oxford, 2013).

Hall, Stuart, Introduction: Who Needs IIdentity`? in: Stuart Hall and Paul Du Gay (eds.), Questions of Cultural Identity (London, 1996) 1-17.

Harrison, Richard J. and Heyd, Volker, The Transformation of Europe in the Third Millennium BC: The Example of \Le Petit Chasseur I+III (Sion, Valais, Switzerland), Prähistorische Zeitschrift 82 (2007) 129-214.

Hauschild, Maya, Schönfelder, Martin, Scheeres, Mirjam, Knipper, Corinna, Alt, Kurt W. and Pare, Christopher, Nebringen, Münsingen und Monte Bibele - zum archäologischen und bioarchäometrischen Nachweis von Mobilität im 4./3. Jahrhundert v. Chr., Archäologisches Korrespondenzblatt 43 (2013) 345-364.

Hedges, Robert, Anglo-Saxon Migration and the Molecular Evidence, in: Helena Hamerow, David A. Hinton and Sally Crawford (eds.), The Oxford Handbook of Anglo-Saxon Archaeo$\log y$ (Oxford, 2011) 79-90.

Hettrich, Heinrich, Die Expansion des Indogermanischen, in: Heinrich Hettrich and Sabine Ziegler (eds.), Die Ausbreitung des Indogermanischen: Thesen aus Sprachwissenschaft und Archäologie. Akten der Tagung der Indogermanischen Gesellschaft vom 24. bis 26. September 2009 in Würzburg (Wiesbaden) forthcoming.

Higham, Nicholas, Rome, Britain and the Anglo-Saxons (London, 1992).

Hills, Catherine, Origins of the English (London, 2003).

Hills, Catherine, Anglo-Saxon DNA? in: Duncan Sayer and Howard Williams (eds.), Mortuary Practices and Social Identities in the Middle Ages. Essays in Burial Archaeology in Honour of Heinrich Härke (Exeter, 2009) 123-140.

Hills, Catherine, The Anglo-Saxon Migration. An Archaeological Case Study of Disruption, in: Brenda J. Baker and Takeyuki Tsuda (eds.), Migrations and Disruptions. Toward a Unifying Theory of Ancient and Contemporary Migrations (Gainesville, 2015) 33-51.

Hodder, Ian, Symbols in Action. Ethnoarchaeological Studies of Material Culture (Cambridge, 1982).

Hofmann, Daniela, What Have Genetics Ever Done for Us? The Implications of aDNA Data for Interpreting Identity in Early Neolithic Central Europe, European Journal of Archaeo$\log y 18$ (2015) 454-476.

Kahrstedt, Ulrich, Politische Geschichte Niedersachsens in der Römerzeit, Nachrichten aus Niedersachsens Urgeschichte 8 (1934) 1-20.

Kazanski, Michel, La diffusion de la mode danubienne en Gaul (fin du IVe siècle - début du VIe siècle): Essai d'interprétation historique, Antiquités Nationales 21 (1989) 59-73.

Kienlin, Tobias L., Von Jägern und Bauern, Theorie(n) und Daten: Anmerkungen zur Neolithisierungsdebatte, Prähistorische Zeitschrift 81 (2006) 135-152. 
Knipper, Corina, Maurer, Anne-France, Peters, Daniel, Meyer, Christian, Brauns, Michael, Galer, Stephen J. G., von Freeden, Uta, Schöne, Bernd, Meller, Harald and Alt, Kurt W., Mobility in Thuringia or Mobile Thuringians: A Strontium Isotope Study from Early Medieval Central Germany, in: Elke Kaiser, Joachim Burger and Wolfram Schier (eds.), Population Dynamics in Prehistory and Early History. New Approaches by Using Stable Isotopes and Genetics. TOPOI - Berlin Studies of the Ancient World 5 (Berlin, 2012) 287-310.

Koch, Alexander, Bügelfibeln der Merowingerzeit im westlichen Frankenreich, Monographien des Römisch-Germanischen Zentralmuseums 41/2 (Mainz, 1998).

Kristiansen, Kristian, Towards a New Paradigm? The Third Science Revolution and Its Possible Consequences in Archaeology, Current Swedish Archaeology 22 (2014) 11-34.

Lidén, Kerstin and Eriksson, Gunilla, Archaeology vs. Archaeological Science. Do we have a Case? Current Swedish Archaeology 21 (2013) 11-20.

Maran, Joseph, Mit den Methoden der Gegenwart in die Vergangenheit - Archäologie und Naturwissenschaften, in: Günther A. Wagner (ed.), Einführung in die Archäometrie (Berlin, 2007) 341-350.

Marciniak, Arkadiusz and Coles, John, Preface, in: Arkadiusz Marciniak and John Coles (eds.), Grahame Clark and His Legacy (Newcastle upon Tyne, 2010) ix-xv.

Miles, Robert and Cleary, Paula, Britain: Postcolonial Migration in Context, in: Dietrich Thränhardt (ed.), Europe - A New Immigration Continent: Policies and Politics in Comparative Perspective, Studien zu Migration und Minderheiten 1 (second edition), (Münster, 1996) 153-176.

Milojčić, Vladimir, Die absolute Chronologie der Jungsteinzeit in Südosteuropa und die Ergebnisse der Radiocarbon-(C14)Methode, Jahrbuch des Römisch-Germanischen Zentralmuseums 14 (1967) 9-37.

Myhre, Bente Magnus and Myhre, Bjørn, The Concept sImmigration< in Archaeological Contexts Illustrated by Examples from West Norwegian and North Norwegian Early Iron Age, Norwegian Archaeological Review 5 (1972) 45-70.

Pattison, John E., Is it Necessary to Assume an Apartheid-like Social Structure in Early Anglo-Saxon England? Proceedings of the Royal Society B 275 (2008) 2423-2429.

Pohl, Walter, Gentilismus, in: Reallexikon der Germanischen Altertumskunde 11 (second edition), (Berlin, 1998) 91-101.

Pohl, Walter, Telling the Difference: Signs of Ethnic Identity, in: Walter Pohl and Helmut Reimitz (eds.), Strategies of Distinction: The Construction of Ethnic Communities, 300-800, Transformation of the Roman World 2 (Leiden, 1998) 17-69.

Pohl, Walter, Die Entstehung des Europäischen Weges: Migration als Wiege Europas, in: Reinhard Neck and Heinrich Schmidinger (eds.), Migration. Wissenschaft · Bildung · Politik 15 (Wien, 2013) 27-44.

Pohl, Walter, Introduction - Strategies of Identification: A Methodological Profile, in: Walter Pohl and Gerda Heydemann (eds.), Strategies of Identification. Ethnicity and Religion in Early Medieval Europe. Cultural Encounters in Late Antiquity and the Middle Ages 13 (Turnhout, 2013) 1-64.

Prien, Roland, Archäologie und Migration. Vergleichende Studien zur archäologischen Nachweisbarkeit von Wanderungsbewegungen, Universitätsforschungen zur Prähistorischen Archäologie 120 (Bonn, 2005). 
Raghavan, Maanasa, DeGiorgio, Michael, Albrechtsen, Anders, Moltke, Ida, Skoglund, Pontus, Korneliussen, Thorfinn S., Grønnow, Bjarne, Appelt, Martin, Gulløv, Hans Christian, Friesen, T. Max, Fitzhugh, William, Malmström, Helena, Rasmussen, Simon, Olsen, Jesper, Melchior, Linea, Fuller, Benjamin T., Fahrni, Simon M., Stafford Jr., Thomas, Grimes, Vaughan, Renouf, M. A. Priscilla, Cybulski, Jerome, Lynnerup, Niels, Lahr, Marta Mirazon, Britton, Kate, Knecht, Rick, Arneborg, Jette, Metspalu, Mait, Cornejo, Omar E., Malaspinas, Anna-Sapfo, Wang, Yong, Rasmussen, Morten, Raghavan, Vibha, Hansen, Thomas V. O., Khusnutdinova, Elza, Pierre, Tracey, Dneprovsky, Kirill, Andreasen, Claus, Lange, Hans, Hayes, M. Geoffrey, Coltrain, Joan, Spitsyn, Victor A., Götherström, Anders, Orlando, Ludovic, Kivisild, Toomas, Villems, Richard, Crawford, Michael H., Nielsen, Finn C., Dissing, Jørgen, Heinemeier, Jan, Meldgaard, Morten, Bustamante, Carlos, O’Rourke, Dennis H., Jakobsson, Mattias, Gilbert, M. Thomas P., Nielsen, Rasmus and Willerslev, Eske, The Genetic Prehistory of the New World Arctic, Science 345 (2014) 1020. Retrieved on 17 September, 2015: science.sciencemag.org/content/345/6200/1255832.

Rummel, Philipp von, Habitus barbarus: Kleidung und Repräsentation spätantiker Eliten im 4. und 5. Jahrhundert, Reallexikon der Germanischen Altertumskunde, Ergänzungsband 55 (Berlin, 2007).

Rummel, Philipp von, Germanisch, gotisch oder barbarisch? Methodologische Überlegungen zur ethnischen Interpretation von Kleidung, in: Walter Pohl and Mathias Mehofer (eds.), Archäologie der Identität. Denkschriften der Österreichische Akademie der Wissenschaften, Philosophisch-Historische Klasse 406, Forschungen zur Geschichte des Mittelalters 17 (Wien, 2010) 51-77.

Sasse, Barbara, Die Westgoten in Südfrankreich und Spanien: Zum Problem der archäologischen Identifikation einer wandernden "gens«, Archäologische Informationen 20 (1997) 29-48.

Schiffels, Stephan, Haak, Wolfgang, Paajanen, Pirita, Llamas, Bastien, Popescu, Elizabeth, Loe, Louise, Clarke, Rachel, Lyons, Alice, Mortimer, Richard, Sayer, Duncan, Tyler-Smith, Chris, Cooper, Alan and Durbin, Richard, Iron Age and Anglo-Saxon Genomes from East England Reveal British Migration History, Nature Communications 7 (2016) 10408. Retrieved on 17 September, 2016: www.nature.com/articles/ncomms10408.

Schiller, Friedrich, Allgemeine Sammlung historischer Memoires vom zwölften Jahrhundert bis auf die neueste Zeiten, 1. Abt., Vol. 1 (Jena, 1790).

Steinacher, Roland, Wiener Anmerkungen zu ethnischen Bezeichnungen als Kategorien der römischen und europäischen Geschichte, in: Stefan Burmeister and Nils Müller-Scheeßel (eds.), Fluchtpunkt Geschichte: Archäologie und Geschichtswissenschaft im Dialog, Tübinger Archäologische Taschenbücher 9 (Münster, 2011) 99-122.

Suhrbier, Stefan, Und bewegten sie sich doch? Die Ausbreitung der schnurkeramischen Kultur in Mitteleuropa, in: Heinrich Hettrich and Sabine Ziegler (eds.), Die Ausbreitung des Indogermanischen: Thesen aus Sprachwissenschaft und Archäologie. Akten der Tagung der Indogermanischen Gesellschaft vom 24. bis 26. September 2009 in Würzburg (Wiesbaden) forthcoming.

Thomas, Mark G., Stumpf, Michael P. H. and Härke, Heinrich, Evidence for an Apartheidlike Social Structure in Early Anglo-Saxon England, Proceedings of the Royal Society B 273 (2006) 2651-2657.

Thomas, Mark G., Stumpf, Michael P. H. and Härke, Heinrich, Integration versus Apartheid in Post-Roman Britian: a Response to Pattison, Proceedings of the Royal Society B 275 (2008) 2419-2421. 
Töpf, Ana L., Gilbert, M. Thomas P., Dumbacher, John P. and Hoelzel, Alan R., Tracing the Phylogeography of Human Populations in Britain Based on 4th-11th Century mtDNA Genotypes, Molecular Biology and Evolution 23 (2006) 152-161.

Trigger, Bruce G., Beyond History: The Methods of Prehistory (New York, 1968).

Trigger, Bruce G., A History of Archaeological Thought (Cambridge, 1989).

Tsuda, Takeyuki, Baker, Brenda J., Eder, James F., Knudson, Kelly J., Maupin, Jonathan, Meierotto, Lisa and Scott, Rachel E., Unifying Themes in Studies of Ancient and Contemporary Migrations, in: Brenda J. Baker and Takeyuki Tsuda (eds.), Migrations and Disruptions. Toward a Unifying Theory of Ancient and Contemporary Migrations (Gainesville, 2015) 15-30.

Weale, Michael E., Weiss, Deborah A., Jager, Rolf A., Bradman, Neil and Thomas, Mark G., Y Chromosome Evidence for Anglo-Saxon Mass Migration, Molecular Biology and Evolution 19 (2002) 1008-1021.

Werner, Joachim, Zur Verbreitung frühgeschichtlicher Metallarbeiten (Werkstatt - Wanderhandwerk - Handel - Familienverbindung), Early Medieval Studies 1 (1970) 65-81.

Wolfram, Herwig, Germanen: Die 101 wichtigsten Fragen (München, 2008).

Woolf, Alex, Apartheid and Economics in Anglo-Saxon England, in: Nicholas J. Higham (ed.), Britons in Anglo-Saxon England (Woodbridge, 2007) 115-129. 